Acta vet. scand. $1974,15,100-110$.

From the Product Development Department, Astra-Ewos AB, the Research Laboratories, Astra Pharmaceuticals AB, Södertälje and the Animal Health Service Department, Swedish Meat Marketing Association, Stockholm, Sweden.

\title{
PROPERTIES OF A COMPLEX OF IRON AND A SORBITOL-GLUCONIC ACID POLYMER FOR TREATMENT OF PIGLET ANAEMIA
}

By

H. Carlsson, S. Lindvall and B. Thafvelin

CARLSSON, H., S. LINDVALL and B. THAFVELIN: Properties of a complex of iron and a sorbitol-gluconic acid polymer for treatment of piglet anaemia. Acta vet. scand. 1974, 15, 100-110. - The properties of a complex of iron and a sorbitol-gluconic acid polymer useful for intramuscular treatment of piglet anaemia have been studied. In rabbits it is well absorbed from muscle and a small percentage $(8 \%)$ of the administered iron is excreted in the urine. A satisfactory utilization of the administered iron for haemoglobin synthesis has been shown in rats. A high degree of tolerance in piglets was observed also for the highest test doses, $600 \mathrm{mg}$ iron per $\mathrm{kg}$ body weight. The clinical utilization was compared to that of iron-dextran using a total of 209 piglets and a dose of $200 \mathrm{mg}$ iron for each animal. Five of these piglets were lost, but these deaths cannot be correlated to the treatment. Of the remaining animals 102 were treated with ISGP and 102 with iron-dextran, and the anaemia-preventing effect was similar for these 2 iron complexes.

haemoglobin synthesis; iron complexes; iron-dextran; iron-sorbitol-gluconic acid polymer; parenteral iron; piglet anaemia; tolerance.

The use of parenteral iron in preventing piglet anaemia is a rational way of treatment. In order to prevent the animals from becoming anaemic during the first 4 weeks after birth, a dose of $200-300 \mathrm{mg}$ of elemental iron is required (Högberg et al. 1968). The toxicity of the iron preparation must be low, since a high dosage has to be administered when the piglets are about 3 days old without regard to the individual weight. In order to reduce the toxicity the iron has to be bound to a stabilizer, which can com- 
bine with the iron to give some form of complex. As stabilizers, carbohydrate-type compounds have been used. All these iron complexes are of a high molecular character. Preparations containing iron-dextran (Barber et al. 1955, Brownlie 1955), hydrogenated iron-dextran (Herin 1962), dextrin-ferric oxide complex (Linkenheimer et al. 1960), polysaccaride-iron complex (Zuschek et al. 1960), iron dextrin complex (Brag 1957) and a complex of iron, dextrin, sorbitol, citric and lactic acid (Högberg et al.), have been reported as being useful in preventing piglet anaemia.

All the stabilizers hitherto used are of natural origin. By reacting epichlorohydrin and sorbitol in alkaline solution it has been possible to synthesize a polymer which can replace for example dextrin in the last preparation mentioned above (Högberg et al.), which contains 2 carboxylic acids, since it has been shown earlier that carboxylic groups are essential for stabilization of certain colloids of iron (Lindvall \& Högberg 1966). In order to synthesize a polymer also containing carboxylic groups a hydrocarboxylic acid has been linked to the sorbitol polymer and it has been shown that it is possible to prepare an iron-containing substance which is stable in aqueous solution at a neutral $\mathrm{pH}$ using a polymer obtained by reacting a sugar alcohol, hydroxycarboxylic acid and epichlorohydrin in alkaline solution (Dahlberg et al. 1973).

This paper presents a report of a study of such an iron complex with regard to resorbability and utilization, especially in preventing piglet anaemia.

\section{MATERIAL AND METHODS}

\section{Iron compounds}

The solution of a complex of iron and a sorbitol-gluconic acid polymer, sterilized by autoclaving, contains $100 \pm 4 \mathrm{mg}$ ferric iron/ml, the $\mathrm{pH}$ being $7.8 \pm 0.6$. It is slightly hypertonic, the depression of the freezing point determined with a Beckmann thermometer is $0.8^{\circ} \mathrm{C}$. It is stable on diluting with saline and has no haemolytic effect. Its LD50 in mice after intraperitoneal injection is $950 \mathrm{mg}$ iron/ $\mathrm{kg}$ body weight. This solution is referred to as veterinary iron-sorbitol-gluconic acid polymer or vet ISGP (Astra 2177, Astra, Sweden).

A solution of iron-dextran (Imposil 200, Fison Pharmaceuticals Ltd, England) containing $100 \mathrm{mg}$ iron/ml was used for comparative purposes in the studies on piglets. 


\section{Animals}

Rabbits. Male albino rabbits with a body weight of $2-3 \mathrm{~kg}$ were used.

Rats. Male albino rats of Sprague-Dawley strain with a body weight of about $300 \mathrm{~g}$ were used. Their haemoglobin concentration was $13.0-16.0 \mathrm{~g} / 100 \mathrm{ml}$ blood and the haematocrit $45 \%$.

Piglets. Twenty-one litters of piglets, cross-bred between Swedish land race and Yorkshire breed were used for the experiment. The litters were housed at 4 farms, 5 litters at each, except for 1 where 6 litters were used. The litters were housed in concrete pens. Equipment of low iron content was used. No creepfeed was given during the first 3 weeks of life. Hygienic conditions were good.

\section{Absorption of iron after intramuscular injection in rabbits}

The iron preparation was injected deep into the glutei of rabbits. The animals were killed at different time intervals after injection and the muscles were dissected away from the leg. The muscles and the skin at the site of injection were homogenized separately with water in a Serwall Omnimixer and aliquots were combusted in a quartz crucible using $\mathrm{Mg}\left(\mathrm{NO}_{3}\right)_{2}$ as oxidizing agent. After dissolving the residue in concentrated hydrochloric acid, the iron was estimated in a Perkin-Elmer atomic absorption spectrophotometer model 403 . The residual iron was obtained by subtracting the iron content of the muscles of the opposite leg.

\section{Determination of iron in urine}

Urine collected from rabbits was diluted with conc. hydrochloric acid, $10 \%$ of the urinary volume. Urine from rats was mixed with $5 \mathrm{ml} 5 \mathrm{M}$ hydrochloric acid, and this mixture was diluted to $100 \mathrm{ml}$ with distilled water. The iron content was directly estimated using a Perkin-EImer atomic absorption spectrophotometer model 403.

\section{Utilization of iron from vet ISGP given to rats}

The experimental design given by Olsson et al. (1972) has been used in experiments on rats kept on a diet containing a low amount of iron (5-8 p.p.m., Astra-Ewos, Sweden) and water with a content of iron of less than 1 p.p.m. The animals were made anaemic by phlebotomy of up to $5.5 \mathrm{ml}$ blood from the or- 
bital vein under a light ether narcosis once a week (first series). When they were stably anaemic (Hb $7.0 \mathrm{~g} / 100 \mathrm{ml}$ blood), they were treated with vet ISGP intramuscularly injected into the right thigh. The increase in haemoglobin level was followed weekly until a stable maximum level was reached, whereupon the animals were phlebotomized again, until they were stably anaemic and had the same haemoglobin level as before treatment (second series). Based on the amount of haemoglobin corresponding to $3.4 \mathrm{mg} \mathrm{Fe} / \mathrm{g}$ taken from the animals, the utilization of the administered iron was calculated.

\section{Tolerance of vet ISGP in piglets}

In order to estimate the tolerance of the iron-sorbitol-gluconic acid polymer, increasing doses were given to 8 piglets at the third day of age. Four doses were given, namely 150, 300, 450 and 600 $\mathrm{mg}$ iron/kg body weight. Two piglets were used at each dose level. The lowest dose was chosen in correspondence with previously used standard doses $(200 \mathrm{mg}$ ) in treatment of piglet anaemia. As the volume of the higher doses will be more than $6 \mathrm{ml}$, the injections were divided and given from both sides of the neck into the occipital muscles.

\section{Prevention of piglet anaemia}

Half the number of piglets in each litter was treated with 200 mg iron as vet ISGP, the other half with $200 \mathrm{mg}$ iron as irondextran. In all, 20 litters were used. The injections were given deep into the occipital muscle. The piglets were marked separately and weighed on the day of treatment and then weighed every or every other week for 6 weeks. At the same time a venous blood sample was taken from the ear and the $\mathrm{Hb}$ was estimated (see also the tables); $0.02 \mathrm{ml}$ blood was haemolyzed in $3.5 \mathrm{ml}$ of $0.1 \%$ sodium carbonate solution or in $5 \mathrm{ml}$ cyanmethaemoglobin reagent and the colour intensity was read in a Linson photometer.

In all experiments the supplementary feed for the piglets was given on the 21 st day after the parenteral injection of iron.

\section{RESULTS}

Absorption of iron after intramuscular injection in rabbits

Veterinary iron-sorbitol-gluconic acid polymer was given to $\mathbf{1 5}$ rabbits at a dose corresponding to $20 \mathrm{mg}$ iron $/ \mathrm{kg}$ body weight. 
The results show that most of the iron was removed from the site of injection during the first days after administration (67\%). After 4 days when $76 \%$ was resorbed there was a slow but continuing resorption, and 32 days after the injection only $10 \%$ of the dose still remained at the site of injection.

\section{Renal excretion}

Nine rabbits were placed in metabolic cages where urine and faeces were separated. The animals were given vet ISGP in a dose corresponding to $20 \mathrm{mg} / \mathrm{kg}$ body weight, and the urine was collected during $24 \mathrm{hrs}$. On estimation of the amount of iron in the urine it was found that the animals excreted about $8 \%$ (range $7-11 \%$ ) of the dose given.

The urinary excretion was also determined in the 3 rats used for studies on the utilizability of vet ISGP and $10 \mathrm{mg}$ of iron was given to each animal. The excretion was followed during $48 \mathrm{hrs}$., and it was found that they excreted 7, 7 and $9 \%$ respectively of the dose given. Ninety $\%$ of the excretion occurred during the first $24 \mathrm{hrs}$.

\section{Utilization of iron from vet ISGP in rats}

Six animals were phlebotomized till they were stably anaemic. Three of them were treated with vet ISGP in a dose corresponding to $10 \mathrm{mg}$ iron to each animal. The other animals served as controls.

The results are given in Fig. 1 and Table 1, and as can be seen from the table the amount of iron which must be taken from the animals in order to have them anaemic was within the range of $5.9-6.9 \mathrm{mg}$. On injection of the iron, the haemoglobin and haematocrit values immediately began to rise and $3-5$ weeks after treatment a maximum value was reached. Five weeks after treatment the animals were phlebotomized again. The weekly measurements of haemoglobin value in control animals corresponded in all to $1.1-1.2 \mathrm{mg}$ of iron. After injection of vet ISGP the weekly controls plus the phlebotomized blood corresponded to 6.4$8.0 \mathrm{mg}$ of iron.

\section{Tolerance of vet ISGP in piglets}

On injection of vet ISGP in doses of $150-600 \mathrm{mg}$ of iron the animals showed no signs of discomfort at any dose level during 


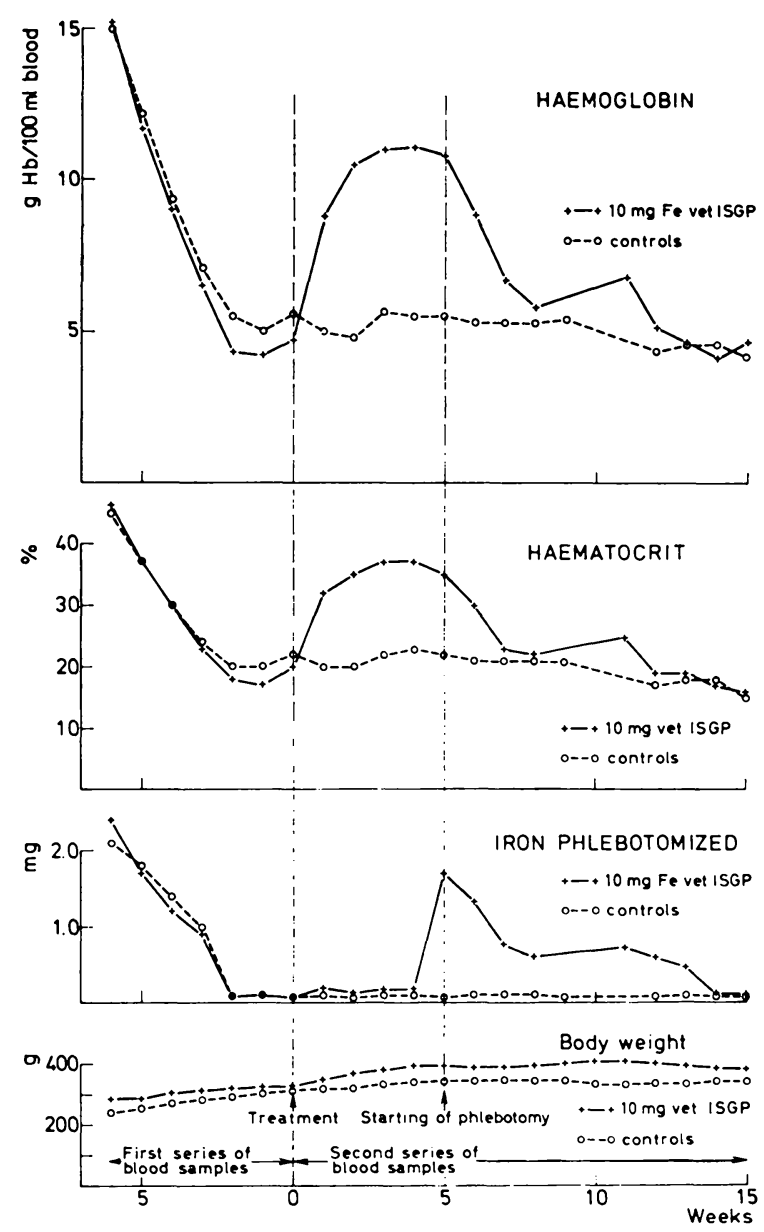

F i g u r e 1. Haemoglobin values, haematocrit values, amount of iron phlebotomized and body weights before and after treatment with veterinary iron-sorbitol-gluconic acid polymer in a dose corresponding to $10 \mathrm{mg}$ of elemental iron to each rat ( 3 animals) and in a control group only phlebotomized to a state of stable anaemia ( 3 animals).

the first $24 \mathrm{hrs}$. or thereafter. No sustained discolouring at 40 days of age could be seen. Four animals were sacrified at 40 days of age by intravenous administration of barbiturate. On necropsy no macroscopic changes were observed with the exception of a slight brownish discolouring of lymph nodes.

The haemoglobin values and body weights were followed once a week during 40 days after birth, and the results are given in 
Table 1. The total amount of iron in blood from untreated rats and from rats before and after intramuscular treatment with vet ISGP. The amount of iron remaining in the body after renal excretion is in brackets.

\begin{tabular}{|c|c|c|c|}
\hline & \multirow[b]{2}{*}{ Rat no. } & \multicolumn{2}{|c|}{ Iron phlebotomized, mg } \\
\hline & & $\begin{array}{c}\text { before } \\
\text { treatment }\end{array}$ & $\begin{array}{c}\text { after } \\
\text { treatment }\end{array}$ \\
\hline 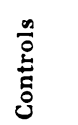 & $\begin{array}{l}1 \\
2 \\
3\end{array}$ & $\begin{array}{l}5.9 \\
6.5 \\
6.9\end{array}$ & $\begin{array}{l}1.1 \\
1.2 \\
1.2\end{array}$ \\
\hline 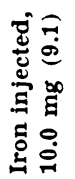 & $\begin{array}{l}4 \\
5 \\
6\end{array}$ & $\begin{array}{l}6.3 \\
6.3 \\
6.0\end{array}$ & $\begin{array}{l}8.0 \\
6.4 \\
6.6\end{array}$ \\
\hline
\end{tabular}

Table 2. As can be seen, all the animals increased their weight during the observation time in the same way irrespective of the different amounts of iron administered. It was also shown that there was no noteworthy difference in the haemoglobin values of the animals during the $\mathbf{4 0}$ days of observation in spite of the different doses given to the animals.

Table 2. Body weight and haemoglobin values during the first 40 days of life in 8 piglets treated on the third day of age with vet ISGP in doses corresponding to $150,300,450$ and $600 \mathrm{mg}$ iron $/ \mathrm{kg}$ body weight. Two piglets for each dosage.

\begin{tabular}{|c|c|c|c|c|c|c|c|c|}
\hline \multirow{3}{*}{$\begin{array}{c}\text { Weeks } \\
\text { after } \\
\text { treatment }\end{array}$} & \multicolumn{8}{|c|}{ Iron, $\mathrm{mg} / \mathrm{kg}$ body weight } \\
\hline & \multicolumn{2}{|c|}{150} & \multicolumn{2}{|c|}{300} & \multicolumn{2}{|c|}{450} & \multicolumn{2}{|c|}{600} \\
\hline & $\begin{array}{l}\text { body } \\
\text { weight }\end{array}$ & $\mathbf{H b}$ & $\begin{array}{c}\text { body } \\
\text { weight }\end{array}$ & $\mathrm{Hb}$ & $\begin{array}{l}\text { body } \\
\text { weight }\end{array}$ & $\mathbf{H b}$ & $\begin{array}{c}\text { body } \\
\text { weight }\end{array}$ & $\mathbf{H b}$ \\
\hline 0 & 2.3 & 8.4 & 2.1 & 8.5 & 2.2 & 8.4 & 2.2 & 6.8 \\
\hline 1 & 3.3 & 7.6 & 2.9 & 6.9 & 3.0 & 7.6 & 3.1 & 6.9 \\
\hline 2 & 4.5 & 10.5 & 4.0 & 10.3 & 4.1 & 9.9 & 4.1 & 9.4 \\
\hline 3 & 6.0 & 11.3 & 5.3 & 11.3 & 5.4 & 10.4 & 5.5 & 10.1 \\
\hline 4 & 7.8 & 11.4 & 7.1 & 10.9 & 7.0 & 10.2 & 7.2 & 10.8 \\
\hline 5 & 9.8 & 11.0 & 9.0 & 11.2 & 8.6 & 10.7 & 9.0 & 10.8 \\
\hline 6 & 11.0 & 10.7 & 11.2 & 9.9 & 10.6 & 11.5 & 11.1 & 11.7 \\
\hline
\end{tabular}


T a ble 3. Mean of haemoglobin values and body weights of 102 piglets treated with vet ISGP and 102 with iron-dextran on the fourth day of age in doses corresponding to $200 \mathrm{mg}$ of iron. In brackets standard deviation.

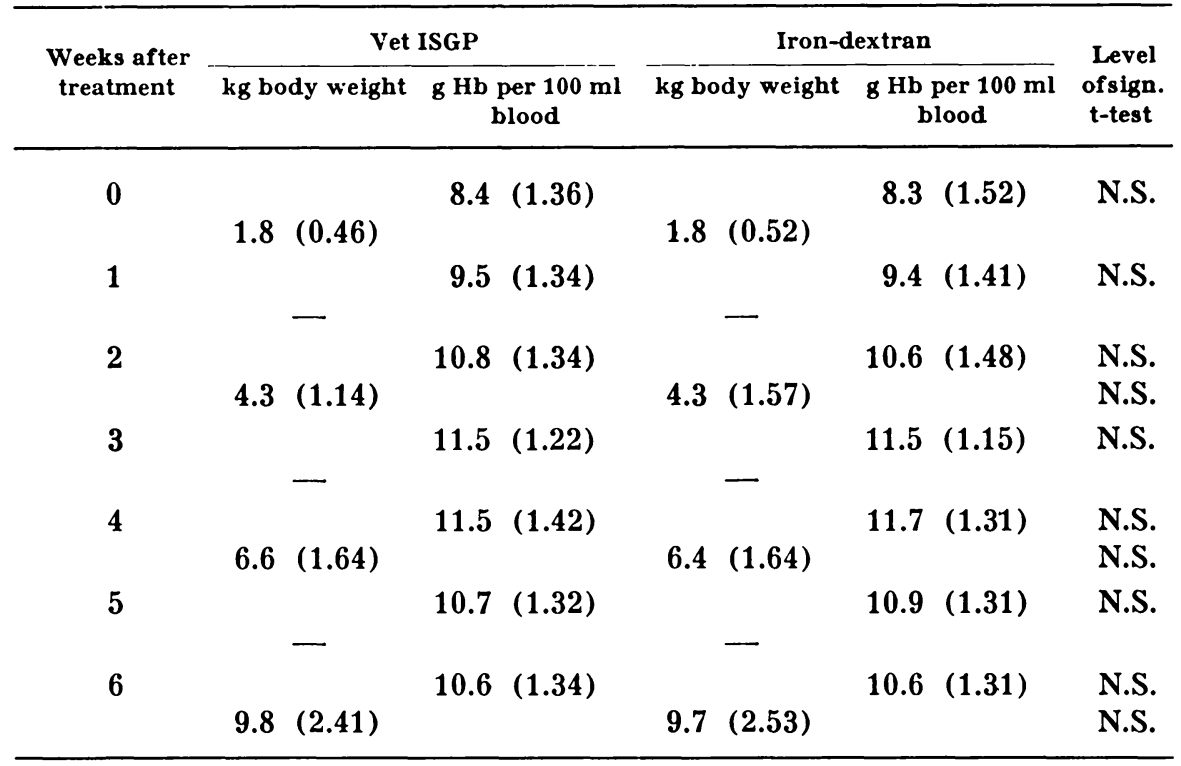

\section{Prevention of piglet anaemia}

In all, 209 piglets have been injected with parenteral iron, the dose being $200 \mathrm{mg}$ of iron, when the animals were $2-4$ days old. One half was treated with vet ISGP and the other with iron-dextran. Five piglets, 3 treated with vet ISGP and 2 with iron-dextran, were lost during the first week. Of these 1 was under-developed and was killed, and 3 were found dead. One was killed 7 days after injection of vet ISGP since this piglet showed posterior paralysis without confirmed aetiology.

The results are given in Table 3 . No significant differences regarding the gain in body weight can be observed when comparing vet ISGP and iron-dextran.

When looking for differences between vet ISGP and irondextran regarding the increase in haemoglobin values no significant differences can be noticed. These values increased after the injection of iron until 4 weeks after treatment. After that time there was a slight decrease, in spite of providing supplementary creep feed containing iron. 


\section{DISCUSSION}

In this study a complex built up of iron and a synthetic polymer was used. The iron in this complex is, according to results using an electrophoretic technique, more firmly bound to the stabilizer than for example in iron-sorbitol where the stabilizer dextrin moves by itself compared to the iron part (Lindvall \& Andersson 1961). It has also been shown that the complex is of a high molecular type. This high molecular size and the firm linkage between iron and the synthetic polymer is the reason for the low acute toxicity in mice and good tolerance in piglets of veterinary iron-sorbitol-gluconic acid polymer.

In spite of the high molecular size the absorption from the muscle after i.m. administration is very high. The absorption of the iron takes place by the lymphatic route without any sign of inflammatory reaction at the site of injection (Lindvall to be published). By using a gel permeation chromatography technique, a wide range of molecular sizes has been noticed, and the reason for the urinary excretion may be that the preparation contains molecules of a size lower than the threshold value for excretion by the kidney. In humans this threshold has been shown to be 50,000-60,000 by Arthurson \& Wallenius (1964) using dextran of different molecular sizes.

Results from the clinical trials of vet ISGP have clearly shown that the iron in the complex is utilized for haemoglobin synthesis in a way similar to the iron in iron-dextran. The duration of the anaemia preventing effect corresponds well to that calculated. A slight decrease in the haemoglobin levels of the piglets was noted in the different tests after they had reached 25 days of age. This result was a direct consequence of the planning of the test, which involved a withdrawal of iron-rich supplementary feed during the first part of the test period. The reason for this withdrawal was to enable a clicinal estimation of the piglets' response to the treatment without interference due to an iron-rich environment.

The comparison of the 2 iron complexes was purposely effected on different farms in different environments. The results could therefore also be interpreted as a limited tolerance test.

The recorded fatalities are to be compared with normal deaths of weak individuals due to natural circumstances. Fatalities were very few, and out of a total of 209 test animals 5 had died. The deaths can in no case be attributed to the iron treatment carried out. 
Increasing doses of $150-160 \mathrm{mg} \mathrm{Fe} / \mathrm{kg}$ body weight were given to pigs under strictly controlled conditions to establish their tolerance limits, the results of which complemented the above mentioned tolerance test. On comparing the effects of the different doses it can be established that an increase in the administered dosage above $150 \mathrm{mg} \mathrm{Fe} / \mathrm{kg}$ body weight did not lead to any further increase in the animals' haemoglobin value. Also a large overdose of iron above the calculated need of the animals during the first 40 days after birth neither inhibited the development nor interfered with their rate of growth.

\section{REFERENCES}

Arthurson, G. \& G. Wallenius: The renal clearance of dextran of different molecular size in normal humans. Scand. J. clin. Lab. Invest. $1964,1,81-86$.

Barber, R. S., R. Braude \& K. G. Mitchell: Studies on anaemia in pigs. Vet. Rec. 1955, 67, 348-349.

Brag, S.: Profylax och järnbristanemi hos spädgrisar. (Profylaxis and iron deficiency anaemia in piglets). Svensk Vet.-Tidn. 1957, 9, $321-323$.

Brownlie, V. M.: The treatment of piglet anaemia. Vet. Rec. 1955, 67, $350-354$.

Dahlberg, A.-G., K.-G. Högberg, S. Lindvall \& T. Rydh: Nouvelle composition contenant du fer, son application médicale et sa préparation. (New composition containing iron, its use and preparation). Belgian patent 1973, number 789, 758.

Herin, R. A.: Toxicologic, hematologic, and growth studies on pigs given hydrogenated iron-dextran intramuscularly. J. Amer. vet. med. Ass. 1962, 141, 1062-1063.

Högberg, K.-G., S. Lindvall, K. Orth, B. Thafvelin \& K. Uthne: Studies on a new intramuscular haematinic for piglet anaemia. Acta vet. scand. 1968, 9, 10-32.

Lindvall, $S .:$ To be published.

Lindvall, S. \& N. S. E. Andersson: Studies on a new intramuscular haematinic, iron-sorbitol. Brit. J. Pharmacol. 1961, 17, 358-371.

Lindvall, S. \& K.-G. Högberg: Iron preparation for intramuscular injection. 1966, US patent number $3,252,863$.

Linkenheimer, W. H., E. L. Patterson, R. A. Milstrey, J. A. Brockman, jr. \& D. D. Johnson: Preparation and biological testing of a parenteral iron preparation. J. Animal Sci. 1960, 19, 763-768.

Olsson, S., O. Lundvall \& A. Weinfeld: Availability of iron stores built up by iron dextrin. Acta med. scand. 1972, 191, 49-56.

Zuschek, F., J. Gillingham \& F. Clark: Clinical studies of parenteral polysaccharide-iron complex. Vet. Med. 1960, 55, 63-66. 


\section{SAMMANFATTNING}

Egenskaper hos ett komplex av järn med en sorbitol-glukonsyra-polymer avsett för profylaxbehandling av smågrisanemi.

Egenskaperna av ett komplex av järn och en sorbitol-glukonsyrapolymer vilket är användbart för intramuskulär behandling av smågrisanemi har studerats. I försök med kaniner har visats en god adsorbtion från muskulaturen och att en liten del $-8 \%$ - av den givna dosen utsöndras med urinen. Ett väntat utnyttjande av den givne dosen för hämoglobin syntes har visats i råttförsök. Smågrisar tolerar komplexet bra även efter den högsta testdosen, $600 \mathrm{mg}$ järn per $\mathrm{kg}$ kroppsvikt. Det kliniska utnyttjandet har jämförts med järndextran $i$ totalt 209 smågrisar med en dos av $200 \mathrm{mg}$ järn per djur. Fem av de behandlade djuren avled, men dessa dödsfall kan ej korreleras till behandlingen. Av de kvarvarande djuren hade 102 behandlats med vet ISGP och 102 med järndextran och den anemiförebyggande effekten var lika för dessa två järnkomplex.

\section{(Received September 22, 1973).}

Reprints may be requested from: S. Lindvall, ASTRA Pharmaceutical AB, S-151 85 Södertälje, Sweden. 